\title{
„Powieść o szwedzkim lęku” czyli kryminał jako zwierciadło zmian społecznych, historycznych i kulturowych na przykładzie cyklu „Wallander” Henninga Mankella*
}

\section{KEYWORDS}

anthropology of literature, popculture, the Swedish literature, crime story, social changes in the 20th and 21th century

\begin{abstract}
Jakubowska Małgorzata Anna, „Powieść o szwedzkim lęku" czyli kryminał jako zwierciadło zmian społecznych, historycznych i kulturowych na przykładzie cyklu "Wallander" Henninga Mankella [,Novel about the Swedish anxiety": crime story as a mirror of social, historical and cultural changes exemplified by the "Wallander" series by Henning Mankel/]. Kultura - Społeczeństwo - Edukacja nr 1(13) 2018, Poznań 2018, pp. 153-168, Adam Mickiewicz University Press. ISSN 2300-0422. DOI 10.14746/ kse.2018.13.12.
\end{abstract}

The purpose of this thesis is to show how popculture works are expressions of the social narrative of historical, social and cultural changes that took place in Sweden in the 90s. This dissertation is based on Henning Mankell's Wallander Cycle. This work will focus on the problem created after 1989 , speciality the problem of immigration and issue of educational values fall.

„Stosować powieść kryminalną jako skalpel odsłaniający ideologiczne zubożenie i moralną wątpliwość tak zwanego państwa dobrobytu typu burżuazyjnego"

Maj Sjöwall \& Per Wahlöö

* W niniejszym artkule wykorzystano fragmenty pracy magisterskiej napisanej pod kierunkiem dr. hab. Sławomira Bobowskiego w Instytucie Filologii Polskiej na Wydziale Filologicznym Uniwersytetu Wrocławskiego w 2015 roku. 


\section{Wstęp}

Cechą kultury popularnej jest jej ścisły związek z rzeczywistością społeczną. Zaliczane do niej teksty muszą nawiązywać do codziennych dylematów odbiorców. Nie może ona funkcjonować bez odwoływania się do podświadomości odbiorcy, jego lęków, nadziei i marzeń. Tylko wtedy może być popularną. „Odbijają się” w niej znaczenia, jakie ludzie nadają swojemu światu społecznemu. To właśnie w dzisiejszej kulturze popularnej unaocznia się trafność określenia, iż kultura jest „rozmową” społeczną (Czerwiński, 1988: 6), na jej bowiem gruncie przeważnie toczy się społeczny dyskurs. Analiza zachodzących w niej zjawisk nabiera tym samym pedagogicznego wymiaru (Jakubowski, 2006). Celem niniejszego artykułu jest pokazanie, że dzieła kultury popularnej są nośnikiem dominujących w społeczeństwie narracji, a zarazem zwierciadłem odbijającym zmiany społeczne, historyczne oraz kulturowe danego okresu w historii świata. Do tego posłużą książki autorstwa Henninga Mankella opowiadające o przeżyciach ystadzkiego komisarza Kurta Wallandera. Praca ta będzie skupiać się przede wszystkim na problemach, jakie pojawiły się w Szwecji po 1989 roku i rozwijają się na przełomie XX i XXI wieku.

Mankell w przedmowie do zbioru opowiadań o komisarzu Kurcie Wallanderze Piramida wspomina o podtytule, którego cały czas poszukiwał: „Powieść o szwedzkim lęku” (Mankell, 2011: 56-57). Autor przyznaje, że jego książki oprócz intrygi kryminalnej przemycają „wariacje na ten sam temat: «Jakie procesy zachodzą w państwie prawa w latach dziewięćdziesiątych? Czy demokracja będzie w stanie przeżyć, jeżeli naruszy się fundament praworządności? Czy szwedzka demokracja ma jakąś cechę, która pewnego dnia zostanie uznana za zbyt wygórowaną?»" (Mankell, 2011: 56-57). Specyfiką tekstów popkultury jest komentowanie czasów, w którym powstają. Dlatego dzieła takie jak film, literatura czy muzyka stanowią doskonałą „piaskownicę” dla archeologa, jakim jest antropolog literatury. W tym miejscu warto przytoczyć wypowiedź Mariusza Czubaja, który twierdzi, że „nie trzeba być jednak fanem powieści kryminalnych, by wiedzieć, że właśnie ten podgatunek przeżywa swój najlepszy czas" (Czubaj, 2012: 5) Liczne reedycje książek, wznowienia, ulepszanie okładek, tworzenie dodatkowych opracowań oraz ekranizacje udowadniają, że powieść kryminalna w XXI wieku wcale nie odeszła do lamusa. Tuż po światowym sukcesie trylogii Millennium Stiega Larssona biura turystyczne zaczęły organizować wycieczki śladami głównych bohaterów książki. Analogiczna sytuacja jest spotykana we Wrocławiu. Przewodnicy oferują podróże tropami Eberharda Mocka - detektywa znanego z książek Marka Krajewskiego, a fani spotykają się, by wspólnie odtwarzać niektóre fabuły. Nasuwa się pytanie: co spowodowało znaczny wzrost fascynacji powieściami kryminalnymi? 
Zainteresowanie kryminałami mogłoby się wydawać niepokojącym zjawiskiem (ze względu na treść powieści) - morderstwa, samobójstwa, handel narkotykami czy okaleczanie innego człowieka nie odzwierciedlają pozytywnych cech człowieczeństwa (o ile w ogóle w tym wypadku można mówić o człowieczeństwie). Raymond Chandler zwraca uwagę, że „zabójstwo, które jest wynikiem frustracji jednostki - a zatem frustracji całego gatunku - może mieć i w rzeczywistości ma wiele implikacji socjologicznych" (Chandler, 1944). Maj Sjöwall wraz z Per Wahlöö próbują wskazać „przyczynę” swoistego boomu powieści kryminalnych, jaki panuje na całym świecie. Zdaniem pisarzy „ta forma literacka jest jak dotąd jedyną, która w rozsądnie przyjemnej i łatwo dostępnej formie odzwierciedla niektóre strony współczesnego społeczeństwa” (Sjöwall, Wahlöö, 2012: 14). W swoich rozważaniach podają przykład „dziedzictwa”, jakie niosą za sobą teksty kultury: „Jeśli za sto lat ktoś zapragnie przeczytać książkę o Nowym Jorku, o tym, jak to miasto wygląda dziś, uważamy, że nie znajdzie lepszych opisów niż na przykład w The Young Prey autorstwa Hillary’ego Waugha, powieści, którą sam autor, w chwili niezwykłej przenikliwości, określił jako «too true to be good»" (Sjöwall, Wahlöö, 2012: 15-16). Książki tworzone współcześnie, które opowiadają o "naszych czasach”, stanowią pewne świadectwo antropologiczne, tego, jak owe dzisiejsze czasy wygląająą. Kryminały, tak jak inne dzieła popkultury, stają się pewnym zwierciadłem, w którym odbijają się zmiany społeczne, historyczne oraz kulturowe. Doskonałym podsumowaniem będą słowa Burszty i Czubaja: „Powieść kryminalna bywa zatem swoistym indeksem zmian w świecie współczesnym, zmian widzianych, co oczywiste, pod określonym kątem i na potrzeby intrygi" (Burszta, Czubaj, 2007: 23).

Wolfgang Iser w swoim artykule Czym jest antropologia literatury? Różnica pomiędzy fikcjami wyjaśniajacymi a odkrywającymi zwraca uwagę na rolę antropologa literatury - ma on za zadanie pokazać nieuchwytną treść, która jest niezauważalna po „Zwyczajnym” przeczytaniu tekstu. Autor w swojej pracy mówi o pojęciu fikcji literackiej, podając definicję przedstawienia rzeczywistości „jak gdyby" - utwór literacki może przy pominać rzeczywistość (por. Iser, 2006: 1135). Jednocześnie „jak gdyby” stanowi pewną tarczę dla autorów powieści, którzy mogą się w ten sposób bronić przed zarzutami ukazania fałszywej rzeczywistości. Doskonałym przykładem fikcji oraz jak gdyby są powieści kryminalne. Autorzy opowiadań, tworząc fikcję, pokazują to, co, ich zdaniem, jest złe i niezauważalne dla większości ludzi. Pisarze tworzą pewną kalkę, która po przyłożeniu do ich powieści wskazuje informacje niedostrzegalne przy „pierwszym” przeczytaniu. Podsumowując myśl Isera, autor pragnie by czytelnik/antropolog nauczył się czytać „między wierszami” i był w stanie wynaleźć to, co jest niepowiedziane wprost. Iser 
w swoich założeniach mocno inspirował się Clifordem Geertzem oraz jego teorią „opisu gęstego". Niniejszy artykuł ma za zadanie odczytać to, co jest niezauważalne dla „Zwykłego” czytelnika. Najpierw należałoby jednak zastanowić się nad samą postacią mordercy ukazaną $\mathrm{w}$ kryminałach Mankella, co ona $\mathrm{z}$ sobą niesie, oraz nad tym, co jest przyczyną tych nagłych zmian w społeczeństwie szwedzkim na przełomie XX i XXI wieku.

\section{Nagłe zmiany}

Pod koniec lat osiemdziesiątych miały miejsce dwa bardzo ważne dla Szwedów wydarzenia: w 1986 roku zamordowano premiera Olofa Palmego, a w 1989 upadł mur berliński. Zamordowanie premiera niesie za sobą pewien niepokój, ludzie, przyzwyczajeni do wolności, związanej z niezagrożonym bezpieczeństwem, odkryli, że ta swobodna przestrzeń została im zabrana. Mankell w jednym z wywiadów tak mówi o tym wydarzeniu:

Jeśli coś w Szwecji pękło, to pewnie od owej fatalnej nocy w 1986 roku, gdy zamordowano premiera Olofa Palmego, wracającego do domu z kina... (...) Śmierć Palmego zawsze będzie traktowana jako ten zwrotny symboliczny moment, który zmienił Szwecję. Nie wydaje mi się, by była to prawda. Gdyby Palme żył, wszystko, co się miało wydarzyć, i tak by się wydarzyło. Mniej więcej od dwudziestu lat możemy obserwować, jak tworzy się społeczeństwo oparte na chorych podstawach. Powinniśmy je reformować i uzdrawiać, nie zaś do reszty zniszczyć. (Burszta, Czubaj, 2007: 205-206)

Zdaniem pisarza, gdyby losy potoczyły się inaczej, wiele w historii społeczeństwa szwedzkiego by się nie zmieniło. Jednak dla mieszkańców Skandynawii wydarzenia z 1986 roku były pewnym sygnałem ostrzegawczym, że ich państwo wraz z nimi zaczyna się powoli zmieniać. Również w książkach Mankella można wyczytać częste refleksje Wallandera oraz jego współpracowników, odnoszące się do zabójstwa Palmego:

Zagadkowe, dotychczas niewyjaśnione zabójstwo szwedzkiego premiera sprzed dziesięciu lat pozostawiło po sobie uraz nie tylko w szeregach policji, ale w dużej części szwedzkiego społeczeństwa. Zbyt wielu ludzi, zarówno w policji, jak i poza nią wiedziało, że zabójstwa prawdopodobnie nie wyjaśniono, dlatego że śledztwo zostało skandalicznie spartaczone już we wczesnym stadium przez samozwańczego i niekompetentnego wojewódzkiego komendanta policji. (Mankell, 2007: 210)

Mankell w ten sposób wkłada w usta Wallandera powszechną opinię, która panuje w społeczeństwie szwedzkim na ten temat. 
Zabójstwo Palmego stanowi pewien początek. Dziewiątego listopada 1989 roku upadł mur berliński, a wraz z nim przestały istnieć „granice” dla wielu państw bloku wschodniego. Dzięki temu możliwa stała się emigracja. Do Szwecji zaczęli napływać imigranci z różnych krańców świata. Upadek muru berlińskiego przeważnie kojarzy się z niezależnością, jednak ta wolność z punkt widzenia Szwedów została im ograniczona ze względu na napływających emigrantów z państw bloku wschodniego. Między innymi dlatego problem imigracji jest tak często poruszany przez Mankella w jego powieściach. W ten sposób mówi Wallander o swojej ojczyźnie:

Oto Szwecja, pomyślał. Pozornie wszystko jasne i świeże, lotniska zbudowane tak, by nie mógł się w nich zagnieździć żaden brud. Wszystko na widoku, wszystko jest tym, na co wygląda. Nasza religia i narodowa nadzieja to bezpieczeństwo, zapisane i zagwarantowane przez prawo, cały świat wie, że śmierć z głodu jest u nas przestępstwem. Nie rozmawiamy z obcymi bez potrzeby, bo oni mogą nas skrzywdzić, zaśmiecić nam kąty, zaczernić nasze neony. Nie zbudowaliśmy nigdy imperium, dzięki czemu nie musieliśmy oglądać, jak się rozpada. Wmówiliśmy sobie, że stworzyliśmy mały, ale najlepszy ze światów. Byliśmy zaufanymi stróżami raju, a teraz, gdy party się skończyło, odgrywamy się najbardziej nieprzychylną kontrolą paszportową na świecie. (Mankell, 2012: 217)

Dla tego cytatu ważny jest kontekst. Wallander wypowiada te słowa podczas podróży służbowej do Rygi, stolicy Łotwy, do niedawna jednej z republik Związku Radzieckiego. Ta podróż dla bohatera jest niezwykle ważna, ponieważ „otwiera mu oczy” na inny świat, po raz pierwszy spotyka się z biedą, korupcją oraz bezustanną walką z ustrojem politycznym. Szwedom najbardziej przeszkadza w imigrantach spotkanie właśnie z tym „innym światem”: nagle muszą nauczyć się żyć wśród odmiennej kultury oraz zwyczajów.

Wydarzenia z 1986 oraz 1989 roku były zaledwie początkiem następnych zajść. Dwa lata po upadku muru Szwedzi przeżyli kolejny szok, a wydarzenia w Sztokholmie stały się dla niektórych głośnym krzykiem społeczeństwa, które nie zgadza się z polityką państwa. Na początku lat dziewięćdziesiątych na ulicach szwedzkiej stolicy pojawił się zamaskowany morderca - snajper strzelający do przypadkowych osób, których wygląd może wskazywać na obce pochodzenie. Obozy dla uchodźców są przeludnione i stają się miejscem częstych zamachów - bramy są obrzucane koktajlami Mołotowa (Tamas, 2013). W wywiadzie udzielonemu Czubajowi i Burszcie Mankell tak mówi o wspomnianych zmianach:

Gdy społeczeństwo przechodzi dogłębną przemianę - taką, jaką na przykład przechodziliście w Polsce po drugiej wojnie światowej - zawsze znajdą się ludzie, którzy będą mieli poczucie, że utracili coś istotnego. I taki właśnie jest Wallander. Krytyczny w stosunku do 
rzeczywistości. A może lepiej powiedzieć, że jest zachowawczy: nie tyle poszukuje czegoś istotnego w przeszłości, ile poważnie wątpi w to, czy zmiany, jakie w Szwecji się dokonują, są zmianami na lepsze [wyróżn. M.A.J.]. (Burszta, Czubaj, 2007: 205)

Dalej wspomina o początkach stworzenia postaci Wallandera: „To był 1989 rok. Wtedy postanowiłem napisać o szwedzkim rasizmie i o tym, jak otwarte społeczeństwo i tolerancyjni zazwyczaj ludzie zmieniają się w ksenofobów. Wtedy też zrozumiałem, że moim bohaterem musi być oficer policji” (Burszta, Czubaj, 2007: 206). Dla autora powieści kryminalnych przełom lat osiemdziesiątych i dziewięćdziesiątych ubiegłego wieku również jest ważnym momentem, zauważa wspomniane zmiany oraz wzrost ksenofobii w państwie szwedzkim. Slavoj Žižek w ten sposób pisze o opowiadaniach szwedzkiego autora: „Mankell przywołuje wszystkie traumatyczne tematy, które dają podstawę do szerzącego się w Szwecji populizmu: napływ nielegalnych imigrantów, wzrost przestępczości i przemocy, rosnące bezrobocie i brak bezpieczeństwa społecznego, rozpad solidarności społecznej... On skupia się na tych, którzy pozostają w cieniu, rozpaczliwe zagubieni w egzystencji” (Žižek). Nie tylko słoweński teoretyk zwraca uwagę na specyfikę „drugiego dna” powieści Mankella. W książce Barry’ego Forshawa o powieściach skandynawskich można wyczytać takie zdanie: „Mankell w swoich powieściach niezachwianie odsłania głęboko zakorzenione podziały w społeczeństwie szwedzkim, wchodząc również w ciemne zakamarki psychiki swoich rodaków" (Forshaw, 2013: 17) ${ }^{1}$. Szwedzki pisarz traktuje swoje powieści jako miejsce do analizy społeczeństwa w którym przyszło mu żyć, wychowywać się oraz dorastać.

Czubaj zwraca uwagę, że „Mankell podejmuje w ten sposób dwa zasadnicze tematy, które w rozległy sposób i w różnych odcieniach pojawiają się w powieściach kryminalnych innych szwedzkich pisarzy. Pierwszą sprawą jest kwestia przemocy. (...) I sprawa druga, którą jest klęska modelu pedagogicznego. Jak to się dzieje, pyta Mankell, że czternastolatek przemienia się w seryjnego zabójcę? Co się dzieje ze szwedzką rodziną i modelem wychowawczym?” (Czubaj, 2010: 318). W poniższym artykule zostanie poddana analiza "upadku modelu pedagogicznego” oraz wpływ imigracji na rozwój przemocy i ksenofobii w Szwecji.

${ }^{1}$ Wszystkie cytaty pochodzące $\mathrm{z}$ prac obcojęzycznych, niewydanych $\mathrm{w}$ Polsce, w niniejszym artykule podaję we własnym tłumaczeniu. 


\section{Imigracja}

W rozważaniach zawartych $\mathrm{w}$ niniejszym artykule niezwykle ważne wydaje się osadzenie współczesnych wydarzeń w kontekście całych dziejów państwa szwedzkiego. Jacek Kubitsky tak pisze we wstępie rozdziału „som invandrare jak imigranci” w swojej książce Alfabet szwedzki: „Historia zaoszczędziła Szwecji doświadczeń wędrówki ludów, najazdów i okupacji przez obce mocarstwa. W odróżnieniu od innych krajów europejskich Szwecja nigdy nie zaznała potężnych wstrząsów politycznych, krwawych rewolucji i zamachów stanu, a przede wszystkim dwóch wojen światowych” (Kubitsky, 2012: 81). Takie „wstrząsy polityczne, krwawe rewolucje oraz zamachy stanu" przyczyniają się do kształtowania tożsamości narodowej oraz są pewnym naturalnym elementem ruchów etnicznych. Wydarzenia na przełomie ostatnich trzydziestu lat stanowią pewien szok dla mieszkańców Skandynawii, rejonu, który do tej pory nie miał za wiele wspólnego z takimi wielkimi tragediami, jakimi były chociażby obie wojny światowe.

Wspomniane wcześniej morderstwo Olofa Palmego stanowi początek tej „rewolucji” w historii. Lata dziewięćdziesiąte rozpoczynają się od wydarzeń w Sztokholmie. John Ausonius (zwany inaczej „człowiekiem-laserem”) terroryzował ludzi, których wygląd wskazywał na obce pochodzenie. Zaledwie ponad dekadę później, w latach 2003-2010, historia się powtórzyła. Szwecja była prześladowana przez Petera Mangsa („snajpera z Malmoe”), niedawno skazanego za swoje czyny. Niedaleko Szwecji, na norweskiej wyspie Utøya, Anders Breivik 22 lipca 2011 roku dokonał zamachu na obóz młodzieżowej Partii Pracy; wcześniej podłożył bombę pod siedzibę premiera Norwegii. Każdy z powyżej wymienionych morderców kierował się jedną pobudką - ksenofobią.

Kraje skandynawskie, które przez setki lat były szczelnie zamknięte na ludność spoza ich regionu, nagle muszą stawić czoła imigracji. „Tubylcom” nie podoba się fakt, że koło ich rodzinnych domów zaczynają tworzyć się zamknięte enklawy, a ich spokojna, opanowana, protestancka kultura miesza się z „kolorową”, gwarną kulturą ludzi z całego świata. Na potwierdzenie tego zjawiska warto przytoczyć dane liczbowe: „W ciągu dziewięciu lat, od 1991 do 2000 roku, Szwecja udzieliła zezwolenia na stały pobyt dla pół miliona cudzoziemców, z których co trzeci podawał się jako uchodźca. Nikt nie wie, ilu prawdziwych uchodźców mieści się w tej kategorii. Doświadczenie podpowiada, że stanowią oni znikomą mniejszość, choć o tym nie należy w Szwecji mówić głośno" (Kubitsky, 2012: 83).

Paradoks imigrantów jest bardzo prosty: z jednej strony Szwecja staje się jałowym, otwartym państwem, które dosłownie jest w stanie przyjąć każdego w swoje progi. Z drugiej strony, poprzez swoje działania (a raczej ich brak) zaczyna zamy- 
kać się na inność, jaką z sobą niesie ludność pochodząca z obcych państw. Kubitsky tak pisze o owym „fenomenie”: „Każdy człowiek, podobnie jak każdy kraj, potrzebuje linii demarkacyjnej. Jest to podyktowane dwoma czynnikami: bezpieczeństwem i wymogiem suwerenności. Świat bez granic jawi się jako pustynia, zaś świat z zamkniętymi granicami staje się więzieniem" (Kubitsky, 2012: 87). Warto teraz przejść do analizy niektórych opowiadań Mankella.

Już w pierwszym opowiadaniu z komisarzem Wallanderem pojawia się problem imigracji. Główny bohater prowadzi sprawę makabrycznego morderstwa pewnego starszego małżeństwa. Jedną z niewielu poszlak, jakie ma, jest słowo wypowiedziane przez ofiarę przed śmiercią: „zagraniczny”. W Mordercy bez twa$r z y$ wiadomo jedno - mordercą jest osoba, która nie jest z pochodzenia Szwedem (bądź Szwedką). Mankell w ten sposób pokazuje lęk Szwedów przed obcością, innością, co często jest utożsamiane z osobami pochodzącymi spoza Skandynawii.

Podczas całego dochodzenia czytelnik jest świadkiem kilku innych „zagranicznych” incydentów. Nie zawsze winę ponoszą imigranci. Dowiadujemy się, że podpalono jeden z ośrodków dla uchodźców, przez co niemalże doszczętnie spłonął, a z kolei jeden z somalijskich uchodźców został zamordowany. Być może Mankell w ten sposób chciał „oczyścić pole walki”, pokazując, że „wina” leży po obu stronach barykady, zarówno wyizolowanych imigrantów, jaki i mocno izolującego się społeczeństwa szwedzkiego.

Pomimo że motyw zbrodni okazuje się błahostką, a mordercy nie mieli na celu żadnych ksenofobicznych działań związanych ze swoim pochodzeniem, Mankell pozostawia pewną otwartą furtkę do dalszych rozważań nad imigrantami w państwie szwedzkim oraz tym, jak obie strony podchodzą do tego problemu. Na przykładzie Mordercy bez twarzy widać, że nie ma jednej „winnej” strony.

Przykład Szwecji jako „więzienia” jest zauważalny w książce Psy z Rygi ${ }^{3}$. Główny bohater, Wallander, odbywa służbową podróż do stolicy Łotwy. Jego działania są podyktowane między innymi poprzez pojawienie się "macek” mafii na terytorium szwedzkim. Do tej pory „zjawisko” gangstera kojarzone jest przez bohaterów opowiadań z kultowymi filmami, takimi jak Ojciec chrzestny, bądź z regionem tak odległym jak Sycylia. Tak Martinsson mówi o „zjawisku” mafii, która jest jednym z elementów powieści Psy z Rygi:

2 W niniejszej pracy zostało podane tłumaczenie Anny Marciniakówny (Mankell, 2004), w innych przekładach można znaleźć tłumaczenie „cudzoziemiec”; oryginalne słowo: unländsk.

${ }^{3}$ Mankell w podrozdziale książki Ręka sam wspomina, że drugi tom powieści miał przede wszystkim za zadanie opowiedzieć (a co za tym idzie, również uświadomić szwedzkich czytelników) o wydarzeniach w Europie już po upadku muru berlińskiego. 
- Mafia - odezwał się Martinsson, który dotąd milczał, ograniczając się do podsuwania Wallanderowi właściwych wyrażeń i słów angielskich - To dla nas coś nowego. Świetnie zorganizowane rosyjskie czy wschodnioeuropejskie syndykaty zbrodni. Kilka lat temu szwedzka policja zorientowała się, że zaczęły się u nas pojawiać szajki sowieckiego pochodzenia, przede wszystkim w Sztokholmie. Ale wciąż wiemy o nich zbyt mało. Kilka brutalnych zbrodni wynikających $\mathrm{z}$ wewnętrznych porachunków stanowiło pierwszą oznakę tego, że coś zaczyna się dziać. I ostrzeżenie, że ci ludzie w ciągu najbliższych lat będą próbowali wbić klin w tutejszy światek przestępczy i zająć w nim kluczowe pozycje. (Mankell, 2012b: 86)

Dla policji z Ystad pojawienie się w Szwecji zorganizowanej przestępczości z Łotwy jest zjawiskiem bardzo abstrakcyjnym, a zarazem absurdalnym. Szokuje to nie tylko mieszkańców, ale również pracowników policji, którzy powinni być zorientowani w tego typu zbrodniach.

Jednak mafia to nie wszystko. W związku z popełnioną zbrodnią Wallander musi odbyć służbową podróż do Rygi. Ten etap jest dla bohatera wbrew pozorom bardzo ważny. Przekraczając granicę Szwecji, poznaje inny, „wspaniały” świat. Zaczyna do niego docierać to, co do tej pory znajdowało się za taflą szkła od telewizora. Ma okazję na własne oczy zobaczyć, na czym polega korupcja oraz państwo pełne politycznych napięć. Główny bohater sam przyznaje, że jest zamknięty na to, co dzieje się poza jego rodzimym krajem:

Wallander wiedział, co miała na myśli. Jeszcze nie minął miesiąc od czasu, kiedy elitarne jednostki sowieckie, zwane czarnymi beretami, ostrzelały budynek ministerstwa spraw wewnętrznych w centrum Rygi. Zginęło sporo niewinnych ludzi. Wallander widział w gazetach zdjęcia barykad, wznoszonych z kamiennych bloków i zespawanych żelaznych rur. Ale mimo to nie bardzo rozumiał, co się właściwie stało. Zaczynał odnosić wrażenie, że zawsze wiedział zbyt mało o tym, co się wokół niego dzieje. [wyróżn. M.A.J.] (Mankell, 2012b: 79)

Wallander, błądząc po Rydze, napotyka grupę konspiracyjną, która stara się pokazać mu, jak naprawdę wygląda życie wysiedleńca na Łotwie i poza nią. Imigranci, którzy poprzez różne sytuacje polityczne, ale również ekonomiczne zostali przymuszeni do opuszczenia ojczyzny, nie chcą utracić swojego pochodzenia. Dla nich życie w państwie tak innym od ich rodzimego jest jednoznaczne z pożegnaniem się na stałe ze swoją kulturą, a przede wszystkim tożsamością narodową. Między innymi dlatego powstają całe getta imigracyjne. Niemniej jednak „wina” leży po obu stronach - imigranci nie okazują chęci do jakichkolwiek zmian, a z kolei Szwedzi, jak dzieci, zamykają oczy, udając, że nie ma żadnego problemu.

Również w Białej lwicy Mankell chce pokazać Szwedom świat, który istnieje poza granicami ich państwa. Informacje, które docierają do mieszkańców Skan- 
dynawii o aparthaidzie, są ignorowane, a większość z nich używa powszechnego zdania „nas to nie dotyczy”. Mankell w tym tomie powieści chce pokazać, że wbrew pozorom, pomimo odległości, Szwecję oraz Republikę Południowej Afryki wiele łączy. Doskonale puentuje powyższą myśl Michael Tapper: „podobnie jak w przypadku postapartheidowskiej RPA Nelsona Mandeli, z pewnych względów, «wielki świat» poza Szwecją nie może być wyłącznie kojarzony z tyranią, przemocą i śmiercią jako wcieleniem zła" (por. Tapper, 2014: 171). Zarówno Szwecja, jak i RPA zamknęły się na „wielki świat” - dla tych państw wszystko, co inne, jest kojarzone $\mathrm{z}$ „tyranią, przemocą oraz śmiercią jako wcieleniem zła”, jednak z czasem okazuje się, że nie do końca tak jest. Wszystko zależy od podejścia, by nie uczynić ze swojego kraju więzienia.

Dla Wallandera każda nowa zbrodnia jest doświadczeniem, z którego wyciąga lekcje. Dowiaduje się więcej nie tylko o samych ludziach, ale również o historii i kulturze innych państw:

W ostatnich latach Wallander wiele razy miał styczność z obcokrajowcami zamieszanymi w różne sprawy. Byli ofiarami przestępstw lub ich możliwymi sprawcami. Jego wcześniejsze wyobrażenia o istnieniu prawd absolutnych, o tym, co dobre, a co złe, o winie i niewinności, wcale nie muszą być powszechnie obowiązujące. Zależnie od pochodzenia, dorastania w określonej kulturze, zmieniały się również kwalifikacje przestępstw. W takich sytuacjach często czuł się bezradny. Brakowało mu wiedzy, jak zadawać właściwe pytania, które mogłyby doprowadzić do wyjaśnienia spraw. (Tapper, 2014: 288)

Wallander z czasem przekonuje się, że nie istnieje jeden, dobry system prawny. Nie ma prawdy absolutnej. Sam o swoich przemyśleniach mówi w ten sposób:

Żyję w kraju, w którym uważamy, że wszystkie prawdy są proste. I niepodważalne. Cały nasz system prawny opiera się na tej zasadzie. Teraz zaczynam sobie uświadamiać, że być może obowiązuje coś wręcz przeciwnego. Prawda jest złożona, wieloznaczna, pełna sprzeczności. Kłamstwo natomiast jest czarne i białe. Inaczej postrzegają prawdę ci, którzy gardzą ludzkim życiem, i ci, którzy je szanują. (Tapper, 2014: 288)

Powyższe zdanie również doskonale pasuje do kolejnego problemu analizowanego w niniejszym artykule, „upadku wartości wychowawczych”. Wallander odkrywa, że „punkt widzenia zależy od punktu siedzenia” i czasami dla kogoś zbrodnią jest zwykła kradzież, a dla innych morderstwo jest rzeczą codzienną, błahą.

Powyższe przykłady stanowią zaledwie część motywów imigracji, jakie przejawiają się w powieściach Mankella. Zostały wybrane te, które dają największe odbicie problemu, z jakim zmaga się Szwecja w ostatnich latach. W Mordercy bez twarzy jest ukazana kwestia imigracji oraz nienawiści z dwóch stron - oso- 
by przybywającej do nowego państwa oraz stałych mieszkańców. W Psach z Rygi oraz Białej lwicy pokazano, jak zamknięcie się na „nowy, wspaniały świat” tworzy problemy, a jednocześnie bariery, które po pewnym czasie są nie do przeskoczenia.

\title{
Kryzys przyjętego w Szwecji projektu pedagogicznego i społecznego
}

\author{
„Powinniśmy się lękać nie amoralności wielkich ludzi, \\ ale tego, że to właśnie ona często prowadzi do wielkości”
}

Alexis de Tocqueville

Kolejnym zagadnieniem poruszanym przez szwedzkiego pisarza jest „klęska modelu pedagogicznego" (Czubaj, 2010: 319) pielęgnowanego przez lata w Szwecji. Jednym z elementów życia, które ma ogromny wpływ na wychowanie, jest praca. Kubitsky, powołując się na myśl Woltera, zwraca uwagę, jaką ogromną rolę w wychowaniu przeciętnego Szweda ma praca. Według francuskiego filozofa „praca pozwala ludziom uniknąć trzech nieszczęść: biedy, występku i nudy" (Kubitsky, 2012: 13). Dla każdego człowieka praca jest bardzo ważna, jednak dla Szwedów to jeden z ważniejszych etapów życia (Kubitsky, 2012: 13). Kubitsky znajduje dwie „przyczyny” takiego przywiązania do pracy: warunki klimatyczne oraz wpływ luteranizmu. (Kubitsky, 2012: 13). Dalej można wyczytać:

Luteranizm - szwedzka wersja protestantyzmu - powołując się na Biblię, podkreślał dobitniej niż katolicyzm znaczenie pracy i jej rolę w kształtowaniu charakteru. Człowiek był - i w zasadzie nadal jest - rozumiany przede wszystkim jako homo faber (łac. człowiek wytwórca), a nie homo ludens (człowiek bawiący się). Praca w pocie czoła była jedną z cnót, które Kościół szwedzki zaszczepiał swoim wyznawcom od początku reformacji w 1527 roku. (Kubitsky, 2012: 14)

Praca stanowi jeden z elementów wychowania młodego człowieka. Równie ważna jest rodzina oraz środowisko, którym otacza się dziecko.

Wallander w Mężczyźnie, który się uśmiechał zajmuje się badaniem morderstwa dwóch adwokatów, ojca i syna - Gustafa i Stena Torstenssonów. W trakcie śledztwa pojawiają się pewne ślady, które prowadzą do Alfreda Harderberga właściciela ogromnej posiadłości, zamku w Farnholmie. Harderberg jest bardzo ważną postacią w szwedzkiej gospodarce, znaną przede wszystkim z działalności charytatywnej. Z czasem okazuje się, że Gustaf Torstensson przed śmiercią, pracując jako adwokat Harderberga, pomaga mu ukrywać niektóre przepływy gotówki. Wallander natrafia na trop nie tylko nielegalnych transakcji finanso- 
wych. Okazuje się bowiem, że cała działalność charytatywna była jedynie przykrywką, zasłoną dymną dla prawdziwego źródła zarobków. Harderberg zajmuje się przede wszystkim handlem ludzkimi organami. Mankell tak pisze o swoich refleksjach omawianej książki:

Punktem wyjścia historii w Mężczyźnie, który się uśmiechał jest najgorszy rodzaj przestępstwa przeciwko mieniu, jakiego można się dopuścić i na jakie można być narażonym. I nie mam na myśli tego, że ktoś został okradziony ze swojego majątku. Tutaj dokonano kradzieży kawałka ciała człowieka, organu, który potem sprzedaje się dalej, do transplantacji. (Mankell, 2013: 119)

Mankell w tej książce pokazuje zachłanność i chciwość, jaką powodują pieniądze. Harderberg nie myślał o pomocy ludziom, a ludzkie organy nazywał „towarem”. Dla niego praca nie kojarzyła się z trudem, ale przede wszystkim z zarobkiem - nie był homo faber, lecz homo ludens; pieniądze dawały możliwości zabawy. Szwedzki pisarz wskazuje również na dwa elementy, które są odpowiedzialne za „upadek wartości” tego wychowania: brak pokory oraz obojętność społeczeństwa szwedzkiego. Wypracowany przez lata luterański model wychowania pokazywał, ile dobrego niesie ciężka praca. Problem zaczyna się pojawiać, gdy ludzie myślą tylko o swojej pracy, a resztę świata traktują jak potencjalny „towar”. Tak jak działo się w przypadku Harderberga. Wallander w ten sposób wypowiada się o swoich przemyśleniach na temat współczesnej gospodarki: „Dotychczas, głębiej się nie zastanawiając, żył z poczuciem pełnego zaufania do tradycji, która głosiła, że szwedzka gospodarka, tak jak małżonka cesarza, jest poza wszelkimi podejrzeniami. Szwedzcy mężczyźni i kobiety, reprezentujący wielkie koncerny, byli fundamentem, na którym wznosił się cud dobrobytu" (Mankell, 2007: 202). Mankell w ten sposób pragnął pokazać, że sukces wielkich koncernów często opiera się na tragedii małych, zwykłych śmiertelników. Niektórzy próbują „odkupić swoje winy” poprzez działalność charytatywną, inni z kolei nie widzą w tym żadnego problemu.

W kolejnym tomie, zatytułowanym Fałszywy trop, jest pewne połączenie obu omawianych problemów: imigracji oraz „klęski modelu pedagogicznego” (Czubaj, 2010: 319). Wszystko zaczyna się od samospalenia młodej, czarnoskórej kobiety na polu zasianym rzepakiem. Wallander nie może pojąć, jak można wybrać tak bolesny rodzaj samobójstwa. Zbrodnia ta sprawia problem nie tylko moralny, ale również prawny, policja nie wie, w jakiej „kategorii” umieścić to przestępstwo: „- Nikt nie popełnił przestępstwa, ale to przecież morderstwo. Zamordowała samą siebie. (...) - Zamordować siebie, a popełnić samobójstwo to nie zawsze to samo (...)" (Mankell, 2012a: 44). Samobójstwo dziewczyny to zaledwie początek, w Ystad pojawia się seryjny morderca, który kolekcjonuje skalpy swoich ofiar. Dla Wallandera 
oraz jego współpracowników to również stanowi szok, tak jak wcześniejsze pojawienie się mafii (Psy z Rygi): „- Do tej pory myślałem, że seryjni mordercy są tylko w USA. Ale żeby tutaj? W Ystadzie? W Skanii?” (Mankell, 2012a: 44).

Okazuje się, że seryjnym mordercą jest czternastoletni chłopiec - Stefan Fredman, który chce zemścić się na swoich oprawcach. Myśli, że uda mu się uratować siostrę, od lat leczoną w szpitalu psychiatrycznym. Pomysł na takie działanie wziął z komiksu. Chłopiec z zimną krwią zaplanował i wykonał cztery morderstwa w tym jedno na swoim ojcu, który sprzedał swoją córkę (wcześniej wspomnianą siostrę Stefana) luksusowej agencji towarzyskiej zapewniającej rozrywkę szwedzkiej elicie 4 . Fredman zakłada tak naprawdę dwie maski: indiańskiego wojownika Geronimo oraz szefa FBI, agenta Hoovera. Prawdopodobnie chłopiec w ten sposób pragnął „oczyścić” swoje działania - zakładając twarz stróża prawa (Hoovera), usprawiedliwia swoje działania, które wykraczają poza prawo szwedzkiego obywatela. Samsel-Chojnacka w analizie postaci Fredmana powołuje się na nordyckie sagi, gdzie zemsta była rzeczą naturalną, a wręcz obowiązkiem (por. Samsel-Chojnacka, 2012: 132).

Mankell w Fałszywym tropie porusza jeszcze jedną ważną kwestię: upadku modelu rodziny. Stefan Fredman wychował się w rodzinie, którą można nazwać patologiczną. Wcześniej wspomniany ojciec Stefana jest drobnym paserem, zdolnym do sprzedania swojej córki. Matka z kolei nie jest w stanie zobaczyć świata bez okularów, jaki stanowi dla niej alkohol. Ojciec jest znany okolicznej policji między innymi przez pobicia, jakich dopuszczał się na ciężarnej żonie - mamie Stefana. Młody chłopiec, przyszły seryjny morderca, nie ma kręgosłupa moralnego, a co za tym idzie, nie zostają mu przekazane odpowiednie wartości wychowawcze. Stefan jako czterolatek tak bardzo bał się swojego ojca, że próbował wydłubać sobie oczy, Wallander tak reaguje na tę wiadomość:

- To niemożliwe. Nie w Szwecji.

- Właśnie w Szwecji. W środku świata. (Mankell, 2012a: 60)

Przytoczone sytuacje stanowią zaledwie część opisywanych przez Mankella przykładów. W Piątej kobiecie Wallander ma do czynienia z bezwzględnym zabójcą, którym okazuje się kobieta - Yvonne Ander. Morderczyni postanawia sama dokonać aktu sprawiedliwości na oprawcach kobiet. Z precyzją planuje kolejne zabójstwa. W tej powieści widać „klęskę modelu pedagogicznego” (Czubaj, 2010: 319) również w policji „Wallander zauważył, że wśród kolegów istnieje zrozumie-

${ }^{4}$ Mankell, opisując tę historię, prawdopodobnie wzorował się na aferze Geijera, która miała miejsce pod koniec lat siedemdziesiątych. 
nie dla postępków Yvonne Ander” (Mankell, 2006). Policja oraz Ander zdają sobie sprawę, że gdyby nie ona, tych zbrodniarzy nigdy by nie dosięgnęła sprawiedliwość. Można śmiało zasugerować twierdzenie, że Ander oraz czternastoletni Fredman z Fałszywego kroku stanowią pewną rozwiniętą opcję Batmana. Z jednej strony wszyscy są wdzięczni Batmanowi, Ander czy Fredmanowi za zrobienie „porządku” na ulicy - w końcu mordują zbrodniarzy, morderców bądź innych, którzy wystają poza margines „normalności”. Z drugiej strony każdy wie, że kodeks Hammurabiego nie funkcjonuje już od dawna, a prawdziwi zbrodniarze powinni być sądzeni przez prawdziwy sąd. Jednak doświadczenie bohaterów mówi, że sprawiedliwość często omija przestępców, a gdy jednak wpadają w ręce policji, to wymiar kary nie zawsze jest równy popełnionym zbrodniom.

W książce O krok komisarz walczy z seryjnym zabójcą, mordującym ludzi młodych i szczęśliwych, stanowiących jego przeciwieństwo. Nie jest w stanie znieść widoku cudzej radości, więc postanawia go unicestwić. Samsel-Chojnacka w swoim artykule Morderca o wielu twarzach. Portrety zabójców w serii o komisarzu Wallanderze powołuje się na myśl Philipa Zimbardo:

Jedną z najgorszych rzeczy, jakie możemy zrobić naszym bliźnim, to odebrać im ich człowieczeństwo, uczynić ich bezwartościowymi przez poddanie ich psychologicznemu procesowi dehumanizacji. Dzieje się tak, gdy uzna się, że „inni” nie mają takich samych uczuć, myśli, wartości i celów życiowych, jakie mamy my. (...) z czasem ten, kto stosuje dehumanizację, daje się pochłonąć przez negatywny aspekt tego doświadczenia, a wtedy zmienia się samo „Ja”, co prowadzi w rezultacie do relacji „Ono - Ono”, relacji między przedmiotami, albo pomiędzy sprawcą a ofiarą. (Samsel-Chojnacka, 2012: 128)

Każdy z powyżej opisywanych morderców doskonale wpisuje się w myśli Zimbardo. Dehumanizując swoje ofiary, przestępcy sami stają się wrakiem człowieka. By dokonać takiej zbrodni, jaką jest odebranie komuś życia, powolnie rozbijają swoje człowieczeństwo na małe kawałki. Samsel-Chojnacka zwraca jeszcze uwagę na pogłębiające się „różnice między bogatymi a osobami wyrzuconymi poza nawias - bezrobotnymi, bezdomnymi (wbrew szczytnym ideom socjaldemokracji wpajanym szwedzkim obywatelom od dziesięcioleci”) (Samsel-Chojnacka, 2012: 131) - dotyczy to zarówno Harderberga, jak i Fredmana.

Od kilku lat na idealnym obrazie kuli, jaką stanowi państwo szwedzkie, zaczynają pojawiać się niekształtne rysy, które z czasem zamieniają się w tytułową „szczelinę"s. Dobrą metaforą do powyższych rozważań Wallandera zdaje się zwykle skaleczenie; gdy organizm jest zdrowy, bez problemu poradzi sobie $\mathrm{z}$ nowo

\footnotetext{
5 Jedna z powieści Mankella nosi tytuł Szczelina.
} 
powstałą raną. Natomiast gdy człowiek choruje, tak jak w tym wypadku choruje społeczeństwo szwedzkie (na znieczulicę oraz zobojętnienie), z czasem kolejne zadrapania nie zostaną tak łatwo opanowane, tak jak jest z „eskalacją przemocy”.

Postać mordercy stanowi pewną personifikację lęku społecznego. Szwedzi najbardziej obawiają się, że ich kręgi kręgosłupa „szwedzkości”, takie jak: praca, rodzina, język, a nawet wygląd, zaczynają powoli wypadać. Wiedzą, że źródłem tych problemów jest polityka prowadzona względem innych państw. Jednak zdają sobie sprawę, że z kraju ludzi tolerancyjnych mogą bardzo łatwo przemienić się w kraj ksenofobów. Postaci takie jak Fredman, Ander czy Harderberg są książkowymi „odpowiednikami” prawdziwych zabójców: Ausoniusa, Mangsa czy Breivika. Z jednej strony czytelnicy czasami utożsamiają się z seryjnymi mordercami, zakładają ich „maski”, by głośno odetchnąć ich powietrzem. Pragną stać się, jak tytułowy bohater z serialu Dexter, „oczyszczający” miasto z innych zbrodniarzy. $\mathrm{Z}$ drugiej strony, odbiorcy wiedzą, że takie poczynania są złe i, zamiast drugim Dexterem, stają się kolejnym Breivikiem. Takie książki stanowią pewien wentyl bezpieczeństwa pozwalający na wyartykułowanie drzemiących w społeczeństwie emocji. Jednocześnie wskazują na to, że coś złego „dzieje się w królestwie szwedzkim", a z drugiej strony jest okazja, by samemu przejrzeć się w tym odbiciu, jakie daje zwierciadło książki.

Zjawisko kryminału antropologicznego zaczyna być popularne na całym świecie, nie tylko w Szwecji, powoli również dociera na polski grunt wydawniczy. Zygmunt Miłoszewski ze swoją trylogią (Uwikłanie [2007], Ziarno prawdy [2011], Gniew [2014]), doskonale wpisuje się w Mankellowski wzór „odbicia” współczesnego świata. Być może w tym tkwi „przepis” na sukces: by nie udziwniać swoich powieści, ale jak najbardziej je urzeczywistnić. Czytając krytycznie powieści kryminalne, wiele możemy dowiedzieć się o naszej rzeczywistości, tak więc na koniec warto przytoczyć sparafrazowany slogan Fidela Castro: „kryminał albo śmierć” (Czubaj, 2012: 5).

\section{Literatura}

Burszta W.J., Czubaj M. (2007). Krwawa setka. 100 najważniejszych powieści kryminalnych. Warszawa. Chandler R. (1944). Skromna sztuka pisania powieści kryminalnych, http://chandler.republika.pl/ skromna_sztuka.htm, dostęp: 12.04.2014.

Czerwiński M. (1988). Przyczynki do antropologii współczesności. Warszawa.

Czubaj M. (2010). Etnolog w mieście grzechu. Powieść kryminalna jako świadectwo antropologiczne. Gdańsk.

Czubaj M. (2012). Kryminał albo śmierć. „Kultura Popularna” nr 2 (31), „Acta Sueco-Polonica” 17. 